\title{
IS THE EUROPEAN GOAL FOR DEFENCE RESEARCH AND TECHNOLOGY EXPENDITURE ATTAINABLE FOR SMALL COUNTRIES?
}

\author{
Prof. Juha-Matti Lehtonen \\ National Defence University, Helsinki, Finland \\ Department of Military Technology \\ email: juha-matti.lehtonen@mil.fi
}

\begin{abstract}
EU Defence Ministers have adopted a joint Strategy on Defence Research \& Technology (RET) that includes a $2 \%$ goal for defence RET expenditure. This paper discusses the feasibility of such a goal for a small country, including the motivations for undertaking defence RET work in small countries, and asks are they different from the large countries?

New and improved weapons systems that create a technological advantage in the battlefield are grounded on research in technology. However, as capability models demonstrate, there are also other aspects of military capability than the materiel which can therefore be a topic for research. Through reviewing a selection of strategy documents from large and small European countries, the fact that only large countries have financial possibilities for major weapons system development and production is highlighted, while in small countries, this link from RET through development to production and operation is broken. Both defence research and defence industrial base figures support this view. Small countries may still have a number of other reasons to engage in RET in either technology or other areas, but these appear not to be able to sufficiently motivate RET expenditure even close to the $2 \%$ level.
\end{abstract}

Keywords: Defence economics, research and technology, research and development, defence industrial base 


\section{Introduction}

The aim of research activities is production of new knowledge, while the goal of development activities is design of new products. Together they are collectively called research and development (R\&D). The opinion as to the right volume, timing and emphasis of defence $R \& D$ varies ${ }^{1}$. For all but a few large producer countries, according to Dunne et al. ${ }^{2}$, budget constraints are such that they cannot afford the massive R\&D required to develop and produce major weapons systems but have to import their major weapons systems.

In 2007, EU Defence ministers adopted the framework for a joint Strategy on Defence Research \& Technology (R\&T) that, among other goals, includes an agreement of a $2 \%$ goal on defence R\&T spending ${ }^{3}$, albeit a voluntary one, without a time limit and applying not at the level of individual but at that of all member states $^{4}$. Not all such international goals are actually attained; for example, the $0.7 \%$ development assistance of gross national product (GNP) goal adopted, as a UN resolution in 1970, has been achieved by only a handful of developed nations and the NATO defence spending guideline of $2 \%$ of GNP was likewise achieved by only a few NATO countries in 2015, namely US, UK, Greece, Estonia and Poland ${ }^{5}$. The objective of this article is to evaluate how realistic such a $2 \%$ R\&T spending goal is for small European countries.

According to Frascati Manual ${ }^{6}$, basic research is the acquisition of such new knowledge where there is no particular application in view, while efforts in

1 A. Middleton, S. Bowns, K. Hartley \& J. Reid (2006) The effect of defence RED on military equipment quality, Defence and Peace Economics, Vol.17 No. 02, pp. 117-139.

2 P. Dunne, M. D. C. García-Alonso, P. Levine, \& R. Smith, (2007). Determining the defence industrial base. Defence and Peace Economics, Vol 18 No 3, pp. 199-221

3 EDA press release refers to government expenditure (or spending) on defence R\&T as investment.

4 EDA (2007) EU Ministers Adopt Framework for Joint European Strategy in Defence R\&T, Press Release, [accessed 10.9.2016] available at: https://www.eda.europa.eu.

5 NATO (2016) Defence Expenditures of NATO Countries, press release, [accessed 9.5.2016] available at: http://www.nato.int/nato_static_fl2014/assets/pdf/pdf_2016_ 07/20160704_160704-pr2016-116.pdf

6 Organisation for Economic Co-operation and Development. (2002). Frascati Manual 2002: Proposed Standard Practice for Surveys on Research and Experimental Development. OECD, p. 30. 
applied research are directed primarily towards a specific practical objective and experimental development aims at producing new products or installing new processes or improving substantially existing ones. Frascati Manual recognises that a cut-off point between experimental development and pre-production activities is difficult to define and that national accounts on defence R\&D include activities that, in its definition, should not be R\&D. EDA defines research and technology $(R \& T)$ as a subset of R\&D that includes expenditure for basic research, applied research and technology demonstration ${ }^{7}$, thereby corresponding to the definition in Frascati manual's basic and applied research. The published data on governmentfunded defence $R \& D$ does not include either privately funded defence $R \& D$ or firms charging for R\&D in product pricing ${ }^{8}$ and similarly the EDA goal of $2 \%$ government spending omits such possibilities of defence R\&T spending.

An R\&T spending goal measures the value of inputs to the knowledge production process. What a country actually needs are the outputs in terms of innovations and new knowledge that in turn enable e.g. new weapons systems that increase its security and benefit the armed forces. Unfortunately, innovation outputs are not as easily measured as resource inputs nor are outputs easily comparable across nations. In fact, assessing organisational effectiveness, i.e. how well an organiszation achieves its goals, has proven one of the more intractable problems in organisation theory ${ }^{9}$. Because of measurement and comparability issues, the EDA target needs to be stated in terms of inputs. However, in the evaluation of the feasibility of a $2 \% \mathrm{R} \& \mathrm{~T}$ spending target, one needs to look at the questions of what goals small countries are pursuing when financing defence R\&T and for what purposes.

The goals and purposes of defence R\&T in both large and small countries is appraised through reviewing official defence strategy documents from selected countries. The strategy documents as a source are by nature diverse, as not all countries have an expressed defence research strategy document. This problem is

7 S. Guzelyte, (2016) National Defence Data 2013-2014 and 2015 (est.) of the 27 EDA Member States, European Defence Agency, Brussels, Belgium. [accessed 10.9.2016] available at: https://www.eda.europa.eu.

8 K. Hartley, (2006). Defence R\&D: data issues. Defence and Peace Economics, Vol. 17 no. 3, pp. 169-175.

9 R. Daft (1986) Organization theory and design, $2^{\text {nd }}$ ed., West Publishing Company, USA. Danish Business Authority, (2014) National Defence Industrial Strategy (pp. 13), [accessed 28.8.2016] available at: https://danishbusinessauthority.dk/industrial-co-operation. 
alleviated by widening the review into defence industrial strategy documents as well as overall defence white papers which include statements regarding defence research. The expressed intentions of a government in such strategy documents may not necessarily be achieved nor may the wording state the actual position but one whose expression better serves the interests of the government. A review of defence research spending statistics and an appraisal of the defence industrial base in selected large and small European countries highlights the current state of affairs. Hartley (2006) cautions that the government-funded defence R\&D data is subject to various limitations associated with reliability, validity and comparability; for the other data in this article, such problems are even more self-evident. With these caveats in mind, a combination of statistics and defence strategy documents enable some initial conclusions to be drawn on the feasibility of the $2 \%$ target.

\section{Defence Research and Development in Defence Context}

In addition to achieving the direct objectives of a new weapon system, $R \& D$ acts as a source of technological advancement and economic growth through what Griliches (1992) calls spill-overs i.e. externalities to other sectors. While there are many examples of defence R\&D spin-offs, there are few studies that quantify their market value ${ }^{10}$. Even though defence R\&D spill-overs are extremely difficult to measure, the overall impression is that they are both prevalent and important ${ }^{11}$. Traditionally, these spin-off results of defence R\&D have been seen as an important argument for defence $R \& D$ because the existence of beneficial externalities makes a case for government subvention to $R \& D$ activity. In post-Soviet years, as the overall defence spending in relative terms in the West has decreased and so has spending in defence R\&D, there is also talk about spin-on i.e. civilian innovations benefiting the military sector.

In the defence and security context, the effectiveness of R\&T policies become strategic because superiority not only relates to market advantages but also entails

10 K. Hartley, (2006). Defence R\&D: data issues. Defence and Peace Economics, Vol. 17 no. 3, pp. 169-175.

11 Z. Griliches, (1992). The Search for R\&D Spillovers, 94 Scandinavian Journal of Economics, Vol 43, No. supplement, pp. 29-47. 
tactical superiority on the battlefield ${ }^{12}$. However, the time needed to transform a new idea that is potentially war-winning to a tangible military capability (e.g. manifested in weapon systems) is lengthy-usually 15 to 20 years $^{13}$. In their extensive study of the effects of R\&D spending on military quality, Middleton et al. (2006) find that the amount of R\&D spending 10-25 years previously affects the average quality of a nation's military systems in operative use. In addition to that, as the quality of military equipment increases over time, the amount of military R\&D spending that enables newer and better equipment can be converted to what Middleton et al. call time advantage, i.e. is the number of years forming a gap between two nations. For example, they calculate that the USA had a sixyear advantage over UK in the 1990s.

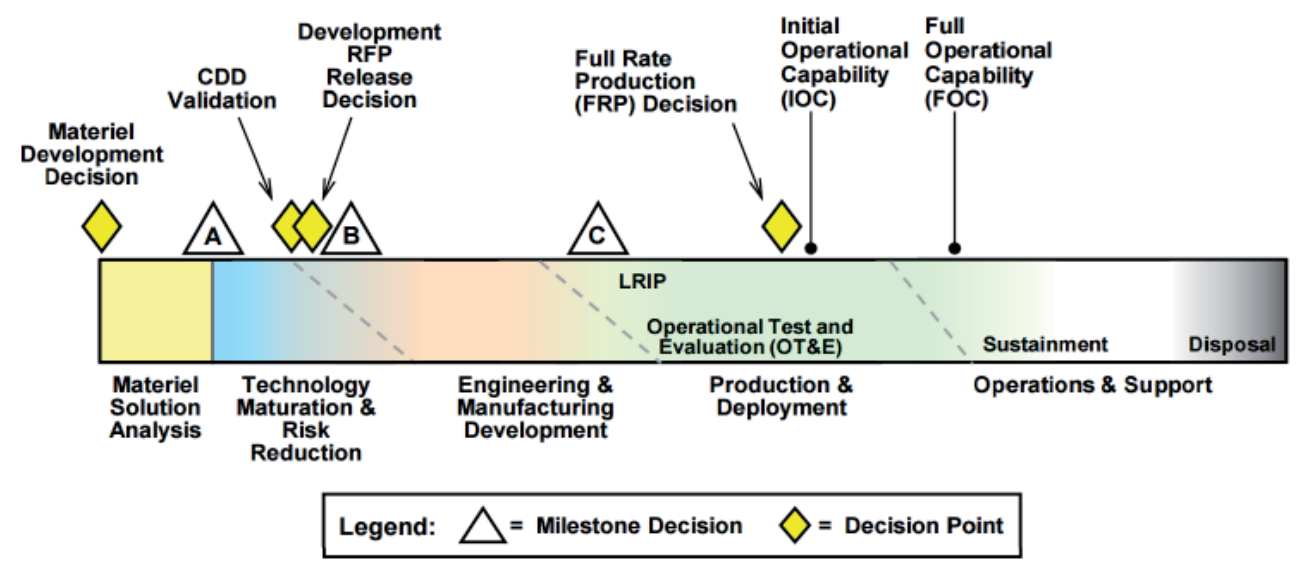

Source: DoD, (2015) DoD Instruction 5000.02: Operation of the defense acquisition system. US Department of Defense, Washington, DC.

Figure 1. Acquisition program model DoDI 5000.02

Figure 1 shows the Department of Defence hardware acquisition program model. In this American model, technology research (R\&T) takes place before the decision for he engineering (R\&D) and manufacturing development phase. As can be seen from figure 1, after product development, the weapon system will be produced

12 D.W. Versailles \& V. Mérindol, (2006). Knowledge transfers and R\&D management: An inquiry into the problem of transatlantic complementarities. Defence and Peace Economics, Vol. 17 No. 3, pp. 239-256.

13 K.P. Reynolds, (2006) Building the Future Force: Challenges to Getting Military Transformation Right, Contemporary Security Policy, Vol. 27 No. 3, pp.435-471. 
and delivered to military units for operative use. A weapons system will then be in operative use for a long time, something like 30 years or more. What is not shown in figure 1 is what takes place before the materiel development decision. When a capability gap is identified and evaluated, if a materiel solution for the capability gap is required, then the acquisition process (figure 1) is initiated. In other cases, some other capability enhancement decision that does not require a materiel solution may be sufficient.

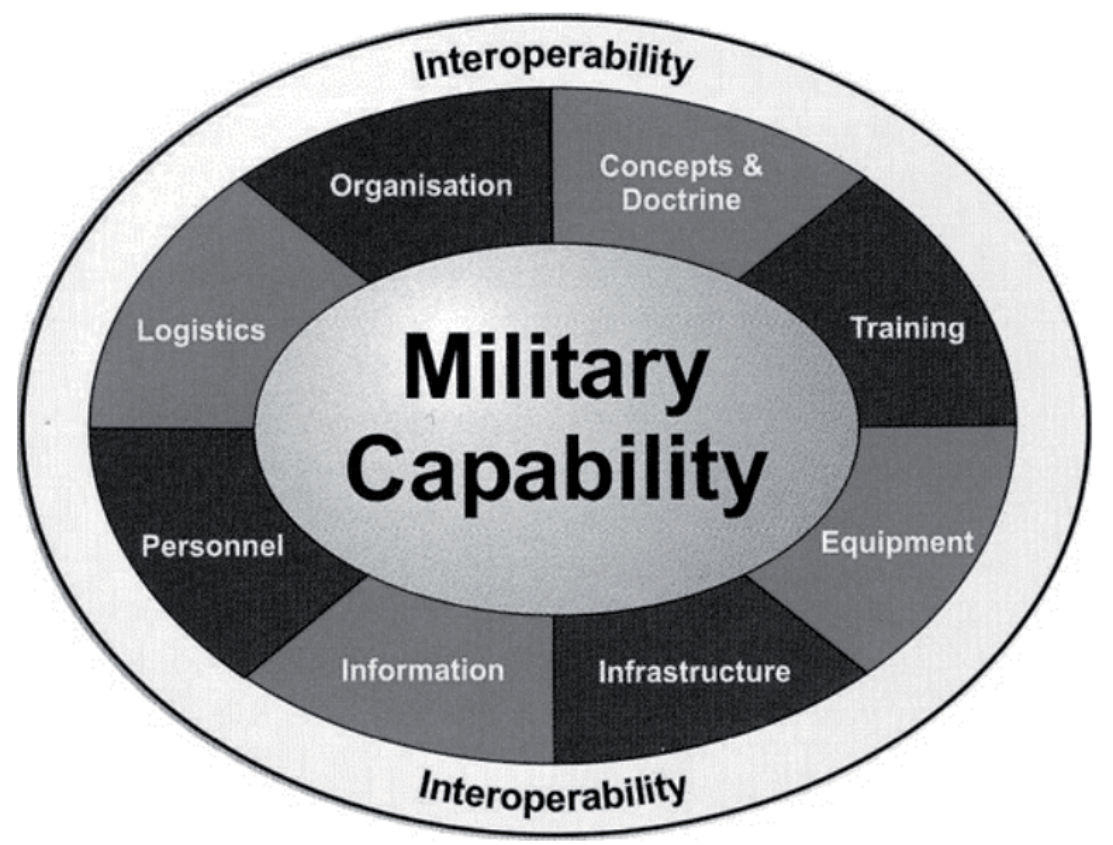

Source: Yue, Y., \& Henshaw, M. (2009). An Holistic View of UK Military Capability Development. Defense \& Security Analysis, 25(1), 53-67.

Figure 2. UK capability areas (Yue \& Henshaw 2009)

A weapon system alone is not sufficient for a military effect. The concept of military capability is used when discussing how to achieve a particular operational effect in time and space. In Australia, for example ${ }^{14}$, military capability consists of organisation, personnel, collective training, major systems, supplies, facilities, support, command, and management. In the UK there are eight such capability

14 The Australian Government Department of Defence (ADoD) (2006) Defence Capability Development Manual, Australia: Defence Publishing Service. 
areas: training, equipment, personnel, infrastructure, concepts \& doctrine, organisation, information and logistics (Figure 2). The desired capability can only be achieved if the activities within all eight capability areas are at an appropriately matched level of readiness, or maturity; failure to manage across all capability areas can lead to serious deficiencies ${ }^{15}$.

Equipment is only one of the eight capability areas in figure 2. Other capability areas can be research topics with a potential for innovations that increase military capabilities. Apart from military capability, there are specific taxonomies for research in general. One is the classification used in OECD R\&D statistics where the top-level groups are: natural sciences, engineering and technology, medical sciences, agricultural sciences, social sciences and humanities. For example, Google Scholar classifies military studies as a subgroup of social sciences. The International Society of Military Sciences has nine working groups including one on military technology. This article started by pointing out the goal of research and production of knowledge. Regardless of the taxonomy applied, it is clear that technology is not the only area of military research with a potential for innovation and military application.

According to Jermalavičius ${ }^{16}$, most non-technological defence R\&D activities are well within the reach of small nations, which have limited resources. As motivation for conducting defence R\&D, Jermalavičius offers the following motivations:

- Assist policymakers in managing uncertainty through security analysis, technology analysis and technology foresight

- To support armed forces (knowledge) needs in capability development, maintenance and use in operations)

- To support armed forces in being "smart buyer" i.e. to support acquisition.

- To promote integration into the Alliance through reciprocal knowledge sharing and participation in common capabilities projects

- To deliver new knowledge and technological solutions for interagency uses in comprehensive security

15 Y. Yue \& M. Henshaw, (2009). An Holistic View of UK Military Capability Development. Defense \& Security Analysis, 25(1), 53-67.

16 T. Jermalavičius, (2009). Defence Research \& Development: Lessons from NATO Allies. p. 40 [accessed 11.8.2016] available at: http://nato.ee/sites/default/files/elfinder/ article_files/icds_report-defence_r_d-lessons_from_nato_allies.pdf, p. 8 . 
- When a sovereignty argument is prevalent in a nation's security policy or when defence industry is a part of national economic development strategy, strengthening the national defence industrial base is a reason, too.

Even though he is writing from a small country perspective, technology features prominently among the list of reasons without even mentioning conducting $R \& D$ for the aim of weapons systems acquisition and production.

\section{The role of defence R\&D in large countries through strategy documents}

The Quadrennial Defense Review states that the United States has long relied on technically superior systems and equipment but that now this superiority is being be challenged by increasingly capable and economically strong potential adversaries.

"The United States has long relied on technically superior equipment and systems to counter adversaries. Our technological superiority has allowed largely unfettered access to project power where needed"17.

US allies are mentioned briefly when ensuring that the investments are "aligned" and "complement" mutual priorities. A strong defence industrial base is called a "national asset" and the Department of Defence expresses its commitment to support the US defence industry. The USA is worried about the future of its technological edge. It still feels that it enjoys both advanced weapons and the cost advantage due to economies of scale. By being able to control the sales of weapons to other nations, the USA also gains political influence ${ }^{18}$.

For the UK, the emphasis is already somewhat different: in addition to technological advantage, the UK also needs a competitive industry in the UK that makes a significant contribution to developing and sustaining key defence

17 C. Hagel, (2014). Quadrennial Defense Review. Office of the Secretary of Defense, p. 25.

18 J. Caverley, (2007) United States Hegemony and the New Economics of Defense, Security Studies, Vol 16 No 4, pp. 598-614. 
and security capabilities. The UK is committed to an open defence equipment market that offers export opportunities for UK-based defence industry as well as value-for-money in its own acquisition, even by buying off-the-shelf equipment when appropriate. To defeat its adversaries, in addition to superior technology and other forms of battle-winning edge, the UK also needs freedom of action through being able to operate and maintain capabilities without being dependent on other nations ${ }^{19}$.

In the French Defence White Paper ${ }^{20}$, France considers the principle of strategic autonomy as important and will ensure that it has the capabilities foroperational action. For this, France needs to preserve a certain number of key technological capacities essential to its strategic autonomy, and to secure the future of the defence industry because of its key role in ensuring strategic autonomy but also for economic and social reasons. However, national security takes place in the framework of NATO and the European Union. European collaboration in armaments, even with its recognised problems, will be sponsored by France.

Germany's defence white paper $^{21}$ sees that armaments-related R\&T activities are a central driver of innovation in the armed forces and the defence industry. Spillover effects into civilian industry (dual-use applications) continue to be a desirable secondary effect and goal of military R\&T. According to Germany's defence industrial strategy ${ }^{22}$, there are key technologies for the defence industry that the government pledges to retain in national hands so that Germany may continue to contribute to international cooperation. Research and development is seen as important for the defence industry and the Government pledges to increase its funding for that purpose while also wishing to see an increased role

19 Ministry of Defence (2012) National Security Through Technology: Technology, Equipment, and Support for UK Defence and Security, White Paper Cm8278, [accessed 11.6.2016] available at: NATO (2016) Defence Expenditures of NATO Countries, press release, [accessed 9.5.2016] available at: http://www.nato.int/nato_static_fl2014/assets/pdf/ pdf_2016_07/20160704_160704-pr2016-116.pdf.

20 Ministère de la Défense (2013) French White Paper on Defence and National Security - 2013, France, p. 135 [accessed 7.9.2016] available at: www.defense.gouv.fr/.

21 The Federal Government of Germany (2016) White paper 2016 on German security policy and the future of the Bundeswehr, [accessed 1.9.2016] available at: https://www. bmvg.de/portal/a/bmvg/en, p. 129.

22 The Federal Government of Germany (2015) Strategiepapier der Bundesregierung zur Stärkung der Verteidigungsindustrie in Deutschland (pp. 13), [accessed 11.8.2016]. 
for the European Commission and EDA in defence research. In contrast to the UK and France, the defence white paper does not mention Germany's freedom of action but stresses German's commitment to cooperative security arrangements in NATO as well as a comprehensive approach. Germany also seems to lack the argument on technological advantage in the battlefield; instead, the emphasis is on industrial and civilian benefits such as spillovers.

\section{The role of defence R\&D in small countries through strategy documents}

Small nations, such as Finland or Denmark, cannot afford to develop either highend military platforms like fighter aircraft or a broad spectrum of weapons, but are buyers in the military market. Although Sweden, especially with its JAS fighter aircraft, qualifies as an exception, even Sweden decided that procurement should focus on equipment existing on the market in 2009, and that new equipment should only be developed as a last resort, when needs cannot be met in any other way ${ }^{23}$.

The Netherlands Defence Industry Strategy of The Netherlands Ministry of Economic Affairs ${ }^{24}$ points out that Dutch Defence Industrial Base (DTIB) consists mainly of small enterprises manufacturing components and subsystems and mainly participates as a subcontractor in supply chains in weapons manufacturing as there are few complete weapon systems manufacturers. The Netherlands is keen to participate and have improved access to supply chains that are currently organised along national lines. Dutch industry is mainly a supplying industry which, in the past, obtained a position in supply chains with the aid of offsets. In order to keep costs down, the $\mathrm{MoD}$, as a rule, acquires equipment off-theshelf, but can deviate from this in specific cases. The economic arguments

23 T. Bertlman and $\AA$ Anclair (2013) International Defence Cooperation Efficiency, Solidarity, Sovereignty; Report from the Inquiry on Sweden's International Defence Cooperation,Fö 2013:B; Swedish ministry of Defence 2013, p. 32, http://www.government. se/reports/2014/10/international-defence-cooperation---efficiency-solidarity-sovereignty. 24 The Netherlands Ministry of Economic Affairs (2013) The Netherlands' Defence Industry Strategy, (pp. 21), [accessed 28.8.2016] available at: https://www.government.nl/ documents/publications/2014/10/22/the-netherlands-defence-industry-strategy. 
feature a prominent role, such as exports, employment, defence R\&T spill-overs to economy and a strong emphasis on open markets that would enable Dutch participation in OEM supply chains. From the military side, there is no mention of security of supply as a factor. Nor are the existence of any specific Dutch requirements mentioned; instead, international cooperation is seen as a necessity in development, production and maintenance of equipment due to the small size of the Dutch defence market.

Danish National Defence Industrial Strategy ${ }^{25}$ recognises that Denmark is a small country with a relatively small defence industry with a few system suppliers and a number of specialised component and subsystem suppliers. Having a subsystem supplier role is seen as a way to establish interdependencies that would increase the likelihood of receiving support from its international partners if the security of Denmark were threatened. With such a standing, Denmark would like to have open defence markets where it could purchase foreign defence equipment and also have free access to foreign defence markets for its own relatively small defence industry, although it is recognised that the international defence market is still characterised by protection of national defence industries. Security of supply (in armaments) is a factor that will be resolved contractually and within EU law. Research is not emphasised but research can help the Danish Acquisition and Logistics Organisation to be a knowledgeable buyer.

According to the Finnish Ministry of Defence's ${ }^{26}$ industrial and technological defence paper, Finland has maintained exceptionally high requirements for military security of supply as Finland is not a NATO member. Because of security of supply considerations, Finland tries to maintain comprehensively technological know-how related to key capabilities as well as an adequate defence industry. As a small country with a limited defence technological and industrial base (DTIB), Finland has to purchase most important weapons systems from abroad. The task for the Finnish DTIB is to manage, modify and maintain these systems so that they can be used when needed, a task that can be interpreted as the level of "freedom

25 Danish Business Authority, (2014) National Defence Industrial Strategy (pp. 13), [accessed 28.8.2016] available at: https://danishbusinessauthority.dk/industrial-co-operation.

26 Finnish Ministry of Defence (2016) Suomen puolustuksen teknologisen ja teollisen perustan turvaaminen (securing Finland's defence technological and industrial base), valtioneuvoston periaatepäätös, [accessed 11.6.2016] available at: www.defmin.fi. 
of action" attainable for Finland. Even so, the document acknowledges that as the weapons systems become increasingly technology-based and complicated, even that level of independence is not easily achieved.

\section{Comparing large and small country Defence R\&D figures}

Table 1 shows R\&T and R\&D expenditures in selected small and large EDA countries. A number of observations can be made from Table 1. First, the absolute amount of $R \& D$ and $R \& T$ spending is many times greater in large countries. In addition to that, as a share, the UK and France both spent over $7 \%$ of their military expenditure on defence R\&D, while of the small countries, only Finland and Sweden spent over $1 \%$. The difference lies mainly in rather non-existent product development of small countries, as is shown in the last column where the UK and France have small values.

\begin{tabular}{|l|r|r|r|r|r|r|r|}
\hline Country & $\begin{array}{l}\text { Defence } \\
\text { expenditure }\end{array}$ & $\begin{array}{l}\text { Percent } \\
\text { of GDP }\end{array}$ & R\&D & R\&T & $\begin{array}{l}\text { R\&D } \\
\text { share }\end{array}$ & $\begin{array}{l}\text { R\&T } \\
\text { share }\end{array}$ & R\&T/R\&D \\
\hline Austria & 2491 & $0.76 \%$ & 1.5 & 1.5 & $0.1 \%$ & $0.1 \%$ & $100.0 \%$ \\
\hline Belgium & 3913 & $0.97 \%$ & 8.1 & 2.6 & $0.2 \%$ & $0.1 \%$ & $32.1 \%$ \\
\hline Finland & 2714 & $1.33 \%$ & 35.1 & 24.7 & $1.3 \%$ & $0.9 \%$ & $70.4 \%$ \\
\hline Netherlands & 7788 & $1.19 \%$ & 59.4 & 59.4 & $0.8 \%$ & $0.8 \%$ & $100.0 \%$ \\
\hline Sweden & 4711 & $1.10 \%$ & 106 & 61.1 & $2.2 \%$ & $1.3 \%$ & $57.9 \%$ \\
\hline France & 39198 & $1.83 \%$ & 3563 & 764 & $9.1 \%$ & $1.9 \%$ & $21.4 \%$ \\
\hline Germany & 34749 & $1.20 \%$ & 846 & 482.9 & $2.4 \%$ & $1.4 \%$ & $57.1 \%$ \\
\hline UK & 48172 & $2.10 \%$ & 3753 & 493.4 & $7.8 \%$ & $1.0 \%$ & $13.1 \%$ \\
\hline
\end{tabular}

Source: Guzelyte, S. (2016) National Defence Data 2013-2014 and 2015 (est.) of the 27 EDA Member States, European Defence Agency, Brussels, Belgium. [accessed 10.9.2016] available at: https://www.eda.europa.eu.

Table 1. Defence spending and defence $R \& D$ and $R \& T$ spending of in selected small and large European countries in 2014 in Milj. $€$

Table 1 also shows how far away from the $2 \%$ R\&T goal small countries are. Only Sweden is over half-way there, while R\&T spending in Austria and Belgium is almost nil. Large countries are closer to the $2 \%$ target, even though none of them is actually achieving the target. At the time the target was adopted in 2007, the 
overall European figure was $1.2 \%^{27}$ while the most recent figure of 2014 is $1.0 \%{ }^{28}$, which is even further away from the goal.

\begin{tabular}{|l|c|c|c|c|}
\hline Country & Investment & Export & Import & Export/Import \\
\hline Austria & 249 & 124 & 24 & 5.2 \\
\hline Belgium & 132 & 198 & 250 & 0.8 \\
\hline Finland & 545 & 332 & 798 & 0.4 \\
\hline Netherlands & 905 & 2791 & 952 & 2.9 \\
\hline Sweden & 1206 & 2095 & 535 & 3.9 \\
\hline France & 10897 & 8034 & 283 & 28.4 \\
\hline Germany & 5324 & 6722 & 571 & 11.8 \\
\hline UK & 9908 & 6476 & 2041 & 3.2 \\
\hline
\end{tabular}

Source: Guzelyte, S. (2016) National Defence Data 2013-2014 and 2015 (est.) of the 27 EDA Member States, European Defence Agency, Brussels, Belgium. [accessed 10.9.2016] available at: https://www.eda.europa.eu

Table 2. DTIB in selected small and large European countries. Export and Import figures 5-year average 2011-15 from Sipri in Million USD ${ }^{29}$; Investment (acquisition) is 2013-14 average in Million Euros by EDA

The export and import columns of table 2 and their relationship in the last column is a measure of the strength of the country's defence industrial base. The first column in table 2 shows weapons expenditure in million Euros and should not be directly compared to SIPRI's trade figures that are in million USD from1990, nor are the periods in question of equal length. However, it gives some idea of the relative volumes of exports and imports to a nation's defence investment when comparing large and small countries as groups. Small countries Finland and Belgium import more than they export, while large countries UK, Germany and France export more, and Austria is not doing much of either. However, the Netherlands and especially Sweden have a considerable export performance when looked at in the context of their national acquisition.

27 EDA (2007) EU Ministers Adopt Framework for Joint European Strategy in Defence R\&T, Press Release, [accessed 10.9. 2016] available at: https://www.eda.europa.eu

28 S. Guzelyte, (2016) National Defence Data 2013-2014 and 2015 (est.) of the 27 EDA Member States, European Defence Agency, Brussels, Belgium. [accessed 10.9.2016] available at: https://www.eda.europa.eu

29 Data from SIPRI is actually based on their Transfer Indicator Value that is an assessment made by SIPRI. TIVs indicate volume in the conventional arms trade and are expressed in 1990 USD. However, they are not necessarily based on actual sales and SIPRI cautions against comparisons to other sources. 
A closer look into SIPRI trade registers reveals that for Sweden, the JAS Gripen fighter deal with Brazil is a major factor, and for the Netherlands, in addition to naval equipment, a number of second-hand equipment deals are also reported. Both Sweden and to some extent the Netherlands are still able to maintain a domestic defence industry with considerable export success even though not at the same level as large countries. As the Middleton et al's (2006) results suggest, R\&D investment made 10-25 years beforehand predominantly determines military equipment quality, and it is possible that the exceptional export performance of Sweden and the Netherlands may decline in the future.

\begin{tabular}{|l|c|l|r|r|r|}
\hline Company & SIPRI Rank & Country & Turnover $(\mathrm{M} €)$ & R\&D $(\mathrm{M} €)$ & R\&D Share \\
\hline Patria & 96 & Finland & 428 & 7.3 & $1.7 \%$ \\
\hline Saab & 37 & Sweden & 2907 & 731 & $25.2 \%$ \\
\hline Kongsberg & 85 & Norway & 453 & 11.1 & $2.4 \%$ \\
\hline BAE Systems & 3 & UK & 24668 & 1740 & $7.1 \%$ \\
\hline Rheinmetall & 31 & Germany & 2240 & 65 & $2.9 \%$ \\
\hline Thales & 12 & France & 12974 & 641 & $4.9 \%$ \\
\hline
\end{tabular}

Table 3. R\&D spending of defence industry national champions. Figures from latest annual report. Sipri rank from www.sipri.org.

Table 3 shows the largest defence company turnovers of three large European nations and three smaller ones from SIPRI's list of top 100 global defence companies. Austria, Denmark and the Netherlands do not have any companies in the top 100 list. $R \& D$ figures include both company own-financed $R \& D$ as well as those financed by customers i.e. nations. Thales and Rheinmetall state that a significant share of R\&D is financed by customers and government agencies, while Saab and BAE Systems give actual figures, where the customer financed part of R\&D is $87 \%$ and $74 \%$, respectively. While the $R \& D$ performed in defence companies is a significant part of total defence $R \& D$, it is also clear that small countries are small in comparison to large countries in this respect. Again, Sweden stands out with Saab's large R\&D. In fact, customer financed R\&D at Saab is about five times more than the R\&D reported by Sweden to EDA. As one of Saab's defence products is the JAS Gripen fighter, one could assume that its development is likely to be a significant part of $R \& D$ expense. It is very hard to believe that some other customer than Sweden would pay for development of JAS. If not, then the R\&D figures reported by Sweden to EDA underestimate the government financed R\&D, even though, in strictly budgetary terms, Sweden may be paying for fighter aircraft, not defence R\&D. 


\section{Conclusions}

From the statistics, it can be concluded that the financial resources and the diverse DTIB required for major weapons systems development are both outside the reach of small countries. The resources available for small countries only enable more limited objectives such as participation in supply chains (the Netherlands) or modifying and maintenance of equipment (Finland). The Netherlands and Sweden, for example, have even expressed a general rule for purchasing off-the-shelf equipment, which means that any weapons development project or participation in one should be an exception. The advanced weapons systems enabling technological advantage on the battlefield are derived from research as e.g. the DoD acquisition model in figure 1 shows. For small countries, however, this link from R\&T through product development to advanced weapons systems is broken, as there is very little product development, nor does the necessarily broad DTIB exist. The lack of military product development in small countries is also apparent in table 1. As technology based advantage and technology R\&T enabling such advantage feature heavily in large country R\&T spending, the absence of this very important motivation makes achievement of comparable R\&T spending unlikely for a small country.

However, there are other possible motivations for small-country defence R\&T as Jermalavičius (2009) pointed out. One reason for small-country technology research is the "better buyer" argument (Denmark). As small countries are mainly buyers, the better buying argument does have some merit but in the overall context of purchasing, the research-based purchasing is not exactly a mainstream approach and, anyway, it may be argued that those resources could be at least equally well used in more thorough evaluation of the actual acquisition alternatives.

An additional argument for small-country technology research is the link through product development to subsystems and components or niche products that offer economic returns in form of exports and jobs. Spillovers may be offered as an additional motivation, but without national security aspects, and is no different from government spending in civilian R\&D that offers prospects of exports and jobs, too. In terms of security benefits of research leading to subsystems and components, allied countries such as the Netherlands may invoke the interdependency, although on the face of it, it contradicts the large-county intention of freedom of action from the security of supply perspective. For a non-allied country, like Finland, which is committed to 
having a full range of capabilities for the task of territorial defence, the subsystems or niche products offer very little in terms of security of supply of a full range of capabilities for military tasks, nor does any possible interdependency i.e. participation in some weapons systems supply chain as a component manufacturer offer much prospect of help in territorial defence from an alliance because it has some component manufacturing ability. Without national security benefits, government support for small country defence technology R\&T does not differ much from supporting civilian $R \& T$, except that the prospects for successful products are probably weaker.

Collaborative product development programmes in the EU or elsewhere could enable small country participation in technology research that would lead to weapons systems. The history of collaborative projects dates back to the early post-war period. In 2007, European Defence Ministers adopted a $35 \%$ target for European collaborative equipment procurement of all defence procurement. In this respect, the decade following the adoption of the ministerial goals has not brought about any noticeable achievement: the share of European collaborative procurement in 2006 was $21 \%^{30}$, while the most recent figure from 2014 is $20 \%^{31}$.

There is then the possibility of defence research in other capability areas than technology and materiel. Jermalavičius (2009) mentioned the support for armed forces in knowledge needs in capability development as motivations for other areas, as well as assistance for policymakers through security analysis and technology foresight. Even though these are all important, there don't seem to be expected benefits that would rival the benefits of technological superiority from technology R\&T through the materiel acquisition process. To give an idea of the volumes in question, let's take as an example the Austrian defence forces. Its personnel is $22800^{32}$ and, if half of the expenditure were spent on personnel and all expenses in e.g. security analysis research were personnel expenses, then attainment of the $2 \%$ goal would translate into about 900 researchers employed in e.g. security analysis.

30 EDA (2007) EU Ministers Adopt Framework for Joint European Strategy in Defence R\&T, Press Release, [accessed 10.9. 2016] available at: https://www.eda.europa.eu.

31 S Guzelyte, (2016) National Defence Data 2013-2014 and 2015 (est.) of the 27 EDA Member States, European Defence Agency, Brussels, Belgium. [accessed 10.9.2016] available at: https://www.eda.europa.eu.

32 The Military Balance (2014) Chapter Four: Europe, Vol 114 No. 1, 59-160. 
In the end, achieving any one commitment on government spending, like $0.7 \%$ development assistance or the $2 \% \mathrm{R} \& \mathrm{~T}$ goal is a political choice and achievable if the political will is there. The reaching of any somewhat arbitrary figure, like $2 \%$ R\&T spending, however, does not in itself accumulate enough political will. The fulfillment of the overall 2 percent R\&T goal will in the future lie on the shoulders of large member states, unless substantial changes are made to collaborative European weapons acquisition policies enabling small country participation on equal footing in the entire acquisition process and, at the same time, making collaborative projects less wasteful in general.

\section{Bibliography}

Bertlman T. and Anclair, A. (2013) International Defence Cooperation Efficiency, Solidarity, Sovereignty; Report from the Inquiry on Sweden's International Defence Cooperation,Fö 2013:B; Swedish ministry of Defence 2013, p. 32, http://www. government.se/reports/2014/10/international-defence-cooperation---efficiencysolidarity-sovereignty

Caverley J. (2007) United States Hegemony and the New Economics of Defense, Security Studies, Vol 16 No 4, pp. 598-614.

Daft, R. (1986) Organization theory and design, $2^{\text {nd }}$ ed., West Publishing Company, USA. Danish Business Authority, (2014) National Defence Industrial Strategy (pp. 13), [accessed 28.8.2016] available at: https://danishbusinessauthority.dk/industrial-co-operation

DoD, (2015) DoD Instruction 5000.02: Operation of the defense acquisition system. US Department of Defense, Washington, DC.

Dunne, P., García-Alonso, M. D. C., Levine, P., \& Smith, R. (2007). Determining the defence industrial base. Defence and Peace Economics, Vol 18 No 3, pp. 199-221.

EDA (2007) EU Ministers Adopt Framework for Joint European Strategy in Defence R\&T, Press Release, [accessed 10.9. 2016] available at: https://www.eda.europa.eu

Finnish Ministry of Defence (2016) Suomen puolustuksen teknologisen ja teollisen perustan turvaaminen (securing Finland's defence technological and industrial base), valtioneuvoston periaatepäätös, [accessed 11.6.2016] available at: www.defmin.fi

Griliches, Z. (1992). The Search for R\&D Spillovers, 94 Scandinavian Journal of Economics, Vol 43, No. supplement, pp. 29-47.

Guzelyte, S. (2016) National Defence Data 2013-2014 and 2015 (est.) of the 27 EDA Member States, European Defence Agency, Brussels, Belgium. [accessed 10.9.2016] available at: https://www.eda.europa.eu

Hagel, C. (2014). Quadrennial Defense Review. Office of the Secretary of Defense. 
Hartley, K. (2006). Defence R\&D: data issues. Defence and Peace Economics, Vol. 17 no. 3, pp. 169-175.

Jermalavičius, T. (2009). Defence Research \& Development: Lessons from NATO Allies. p. 40 [accessed 11.8.2016] available at: http://nato.ee/sites/default/files/elfinder/ article_files/icds_report-defence_r_d-lessons_from_nato_allies.pdf

Middleton A., Bowns S., Hartley K., \& Reid J. (2006) The effect of defence RED on military equipment quality, Defence and Peace Economics, Vol.17 No. 02, pp. 117-139.

Ministère de la Défense (2013) French White Paper on Defence and National Security - 2013, France, p. 135 [accessed 7.9.2016] available at: www.defense.gouv.fr/

Ministry of Defence (2012) National Security Through Technology: Technology, Equipment, and Support for UK Defence and Security, White Paper Cm8278, [accessed 11.6.2016] available at:

NATO (2016) Defence Expenditures of NATO Countries, press release, [accessed 9.5.2016] available at: http://www.nato.int/nato_static_fl2014/assets/pdf/pdf_2016_ 07/20160704_160704-pr2016-116.pdf

Organisation for Economic Co-operation and Development. (2002). Frascati Manual 2002: Proposed Standard Practice for Surveys on Research and Experimental Development. OECD.

Reynolds K.P., (2006) Building the Future Force: Challenges to Getting Military Transformation Right, Contemporary Security Policy, Vol. 27 No. 3, pp.435-471.

The Australian Government Department of Defence (ADoD) (2006) Defence Capability Development Manual, Australia: Defence Publishing Service.

The Federal Government of Germany (2015) Strategiepapier der Bundesregierung zur Stärkung der Verteidigungsindustrie in Deutschland (pp. 13), [accessed 11.8.2016].

The Federal Government of Germany (2016) White paper 2016 on German security policy and the future of the Bundeswehr, [accessed 1.9.2016] available at: https://www.bmvg. $\mathrm{de} / \mathrm{portal} / \mathrm{a} / \mathrm{bmvg} / \mathrm{en}$

The Military Balance (2014) Chapter Four: Europe, Vol 114 No. 1, 59-160

The Netherlands Ministry of Economic Affairs (2013) The Netherlands' Defence Industry Strategy, (pp. 21), [accessed 28.8.2016] available at: https://www.government.nl/ documents/publications/2014/10/22/the-netherlands-defence-industry-strategy

Versailles, D. W., \& Mérindol, V. (2006). Knowledge transfers and R\&D management: An inquiry into the problem of transatlantic complementarities. Defence and Peace Economics, Vol. 17 No. 3, pp. 239-256.

Yue, Y., \& Henshaw, M. (2009). An Holistic View of UK Military Capability Development. Defense \& Security Analysis, 25(1), 53-67. 